\title{
Forord til RvT 69: forløsning og urenhed
}

Størstedelen af bidragene til dette nummer af RvT angår forholdet imellem to størrelser der umiddelbart kunne forekomme ikke at have specielt meget med hinanden at gøre: På den ene side 'urenhed', og dermed også anomisk adfærd, fx i omgangen med døde mennesker, på den anden side 'forløsning' i prægnant forstand, dvs. forløsning - eller frelse, befrielse - fra den jordiske, almindelige virkelighed, herunder ikke mindst netop den legemlige død. Udgangspunktet for bidragene til dette tema er et seminar, afholdt ved Afdeling for Religionsvidenskab, Aarhus Universitet, 18. dec. 2017. Som inspiration for oplægsholderne var udleveret en præsentation af den tese der er udfoldet i nummerets første bidrag, Hans J. Lundager Jensens artikel om vejen til himlen igennem urenhed. Den kosmologiske transformation der gjorde himlen til et dødsrige, blev ledsaget af en transformation af synet på døden hvor døde kroppe ikke længere var det modsatte af det guddommelige, men selve vejen dertil. Tankegangen minder om visse former for radikal tantrisme, der måske kan bruges som en 'etic'-term, dvs. som en generel bekrivende term for lignende religiøse fænomener også uden for den indiske kontekst.

Seminaret inspirerede til en række artikler, hvoraf nogle ligger parallelt med eller i forlængelse af indledningsartiklen, mens andre modificerer tesen eller går i andre retninger - samtidig med at relationen urenhed og forløsning fastholdes. Kritisk i forhold til udgangstesen påpeger Jørgen Podemann Sørensens artikel "I begyndelsen var snavset ..." eksempler på positive vurderinger af det urene, inkl. anomisk adfærd, i før-aksiale religioner som japansk (shinto), egyptisk, indisk og græsk religion, dvs. religioner der ikke befordrede forløsning fra den jordiske verden, men støttede op om og gav mening til det menneskelige liv på de givne og kendte vilkår. Lars Albinus viser i sin artikel om den orfiske retning i græsk religion hvordan orfikerne, et tidligt eksempel på en aksial religion, på en umiddelbar paradoksal måde rensede sig igennem særlig ekstreme former for urenhed og dermed forløstes fra genfødslernes evige gentagelse. Anders Klostergaard Petersens artikel om den stinkende Paulus fokuserer med udgangspunkt i en scene fra Dostojevskis roman Brødrene Karamasov på Paulus' radikale omvending: De traditionelt-arkaiske religioner sværmede for den guddommelige vellugt; i den aksiale omvending måtte de, der kunne frelses, derfor blive dem der stank af død.

Johanne L. Christiansen giver i sin artikel om beskidte ting i islam to eksempler på anomisk adfærd: dels pilgrimmes pålagte usoignerede tilstand, dels visse sufiers beruselsespraksis. Det første tilfælde er velintegreret i normal islam; det andet er problematisk og på kanten. Fælles for dem er at det ikke er overholdelsen af regler, men 
brud på dem, der fører de særligt engagerede mennesker tættere på det guddommelige. At vejen til frelse også i en jødisk kontekst kan forestilles at gå igennem urenhed, synd og død, viser Marianne Schleicher i sin artikel om mystikeren Shabbetai Tsvi, der konsekvent brød med normalt indiskutable regler i jødedommen og som i 1666 'omvendte' sig til islam, dvs. påtog sig den dybeste fornedrelse - i forventningen om Messias' forestående komme.

Den indiske og østasiatiske dimension på dette nummers tema undersøges i tre bidrag. Mikael Aktors artikel om 'respect pollution' undersøger den paradoksalt positive værdi, urene materier kan få, hvis de stammer fra hierarkisk højerestående personer og håndteres respektfuldt af hierarkisk laverestående; i et højaktuelt efterskrift efter færdiggørelsen af artiklen viser Aktor at forestillinger om urenhed og hellighed stadig har et stort konfliktpotentiale i nutidens Indien. Af Marianne Qvortrup Fibigers artikel om Kāmākhya, en betydningsfuld gudinde i tantrisk hinduisme, fremgår at menstruationsblod, normalt et stærkt urent stof, kan være positiv og velgørende når det kommer fra en gudinde, men også at den positive effekt har to sider: umiddelbart lykkebringende for lægfolk, men forløsende for de konsekvente 'hard core'-tantrikere. Modsætningen imellem regler for det brede lægfolk og regelbrud for konsekvente individualister er også et tema i Jørn Borups bidrag om chan-/zen-buddhismen der i ganske særlig grad har givet plads til anomi, værdiomvending, galskab og hellige fjolser og til hvad der umiddelbart kan se ud som en ligefrem afvisning af buddhismens relevans. Eksplicit anti-religiøs var endelig den fransk-rumænske forfatter Emil Cioran der i særlig grad formulerede en negativ holdning til den menneskelige tilværelse; eksistensen er en sort ulykke, og der er ingen gud der kan forløse. Dét var stof for litterær høj-niveauproduktion, og Erik Sporon Fiedler introducerer i sin artikel både til Cioran og til dennes tyske beundrer, filosoffen Peter Sloterdijk, der ikke kunne undgå at se en åndsbeslægtethed med de mest radikale strømninger tilbage i religionshistoriens aksiale gennembrud.

Uden for temaet - men ikke uden for den bredere, religionshistoriske ramme, som disse bidrag placerer sig inden for - er Nikolaj Skou Haritopoulos' artikel om helgenverdenen i Skive kirke, hvis kalkmalerier er den mest fuldstændige billedfremstilling på dansk grund af hovedskikkelser i en kristen mytologi, som var engang. Artiklen viser også at dette inventar af opmærksomhedsindfangende personligheder kunne organiseres på en måde der ikke var fjern fra en meget tidligere, arkaisk kulturs principper.

Ud over artikler rummer dette nummer et gensvar fra Anders Klostergaard Petersen til kritikken i nr. 68 af hans anmeldelse i nr. 67, samt en længere anmeldelse fra samme hånd af en nyudkommet dansk bog om kristne temaer. Nummeret rummer desuden en række anmeldelser af aktuelle og relevante publikationer.

Dette temanummer ligger i naturlig forlængelse af tidligere temanumre af RvT, således nr. 60 om Robert Bellah og aksetidsteori og nr. 64 om askese. Temaer, informationer og teorier i én artikel dukker op i en anden og en tredje, og artiklerne henviser 
til hinanden på kryds og tværs. Som i tidligere temanumre kan også artiklerne i dette nummer 69 af RvT derfor ses som bidrag til en antologi. Artiklerne er blevet til i et diskuterende miljø, hvor forskere fra meget forskellige områder reflekterer over sammenlignelige problemstillinger. Men disse overlap fremgår kun for den der læser flere eller alle artiklerne, og redaktionen har med vilje ikke gjort noget forsøg på at pille gentagelser ud. Hver artikel skal kunne læses og bruges for sig, uden andre nødvendige informationer end dem der gives i artiklen selv som referencer og fodnoter; derfor redegør også hver enkelt artikel for sine teoretiske udgangspunkter.

Et gennemgående tema i nummeret her er sondringen imellem før-aksiale religionsformer og aksiale bevægelser. De førstnævntes grundlæggende formål, at stabilisere og fremme et materielt lykkeligt liv og social sikkerhed, omsættes i regler, tabuer og love, som så rammes og negeres af værdiomvendingerne i de sidstnævnte. Men flertallet af de religioner der undersøges i disse artikler, er hverken rent arkaiske eller rent aksiale. Fælles for dem er at de etablerer en art spændingsfyldt ligevægt imellem norm-bekræftelse og norm-brud, imellem en forestilling om det vigtige $i$ at overholde regler og det potentiel frigørende $i$ at bryde dem, dvs. en spænding imellem at bekræfte 'verden' og i at forlade eller bryde med 'verden'. For såvel buddhisme som hinduisme, islam, jødedom og kristendom synes begrebet om 'post-aksial' religion at give god mening. - En relateret problemstilling dukker op i både Marianne Schleichers og Anders Klostergaard Petersens artikler: Philippe Descolas forestilling om en 'analogistisk' ontologi, dvs. en grundlæggende forestilling om at alt hænger sammen i en harmonisk enhed, og som umiddelbart synes rammende som beskrivelse for de typiske monistiske harmoniforestillinger i arkaiske religioner - kan og bør den tænkes sammen med de aksiale tankeganges dissonantiske dualismer, der netop var kritisk distanceret fra, eller ligefrem forkastede, de arkaiske religioners harmoniserende optimisme?

$* * *$

Bagerst i hvert nummer af RvT er en liste over bøger som redaktionen har modtaget. Denne liste er i første omgang en kvittering og en tak til de forlag der har tilsendt bøgerne. Men den er også en indirekte opfordring til læsere om at skrive en anmeldelse. Vi får flere bøger tilsendt, end vi kan anmelde, og vi må foretage et udvalg. RvT publicerer gerne anmeldelser også af de bøger vi ikke selv har fundet en anmelder til. Så interesserede er velkomne til at henvende sig til redaktionen.

$* * *$

Artiklerne i dette nummer er som sædvanligt fagfællebedømte efter retningslinjerne i Uddannelses- og forskningsministeret. Redaktionen oplever stor velvilje fra kolleger og eksperter, der gerne og med relativt kort varsel påtager sig opgaven at læse manuskripter igennem og levere nødvendig kritik og nyttige forslag til forbedringer. Redaktionen vil her gerne kvittere med stor tak til fagfællebedømmerne. 
Hans J. Lundager Jensen, professor, dr. theol. Afdeling for Religionsvidenskab, Aarhus Universitet hj@cas.au.dk

Johanne Louise Christiansen, postdoc, ph.d. Afdeling for Bibelsk Eksegese, Københavns Universitet jch@teol.ku.dk

Katrine Frøkjær Baunvig, lektor, ph.d. Grundtvig Centeret, Institut for Kultur og Samfund, Aarhus Universitet baunvig@cas.au.dk 